\title{
Conservation, Counter-culture, and Separate Realities
}

\author{
by
}

Raymond F. Dasmann, Ph.D. (Calif.)

Senior Ecologist, International Union for Conservation of Nature and Natural Resources (IUCN), 1110 Morges, Switzerland.

\section{INTRODUCTION}

The task of keeping up with 'the literature' is a responsibility for all who work in the environmental sciences. The difficulties increase with the volume of publications. Environmental studies can encompass the full range of human interests from anthropology to zoology, and one knows not in which field the next important breakthrough may occur. To add further to the reading problem, concepts of great value to those concerned with conservation may arise from unexpected sources. It is the purpose of this paper to examine certain areas of human activity or human inquiry and consider their possible significance to conservation. It is in one sense an account of my own intellectual wanderings and is at best a layman's guide to some of the subjects to be discussed.

During the 1960s, many parts of the world were swept by an unexpected wave of activism which tended towards complete social rebellion. This can be said to have had its first major expression in the student revolt at the University of California in Berkeley during 1964-65. Although young people were prime movers, this activism, at least in the United States, affected all members of the intellectual community as well as the public in general. There were few neutrals but much strong emotion was expressed for or against. The French writer Jean-François Revel stated, as a sub-title to his book Without Marx or Jesus, that The New American Revolution Has Begun (1971 [1972]). Charles A. Reich examined the significance of what he entitled The Greening of America (1970 [1971]) and concluded 'There is a revolution coming. It will not be like revolutions of the past. It will originate with the individual and with culture, and it will change the political structure only as its final act. It will not require violence to succeed, and it cannot be successfully resisted by violence. This is the revolution of the new generation.' Theodore Roszak examined the rationale of the new movement in The Making of a Counter-culture: Reflections on the Technocratic
Society and its Youthful Opposition (1968 [1971]). In a more light-hearted, but essentially accurate, account, Tom Wolfe examined the psychedelic origins of the movement in his The Electric Kool-aid Acid Test (1968 [1969]).

\section{EFFECTS OF THE COUNTER-CULTURE}

In 1974, journalists are inclined to look back on the events of the 1960s as a temporal phenomenon that is now past, and to regard the accomplishments of the counter-culture as negligible in significance. This may result as much from a failure to understand what was going on as from failure to observe what is still taking place. More recently, various books have appeared which develop a deeper perspective on the counterculture and its probable future. Noteworthy are George B. Leonard's The Transformation (1972), Theodore Roszak's Where the Wasteland Ends (1972), and Robert Houriet's Getting Back Together (1973).

It is perhaps impossible to describe briefly what has been a polymorphic, shape-changing, wave of revolt against traditional societal attitudes and values. Its emotions have been expressed best in the new music which has seemed like no music at all to those who were not 'tuned in.' However, one cannot ignore the influence of Bob Dylan, Pete Seeger, or Joni Mitchell, in the United States, and of The Beatles and The Rolling Stones in the United Kingdom, in giving focus to the feelings of the 1960s' generation. The ideology of the movement can scarcely be described at all. Perhaps its greatest feature was its lack of any fixed ideology. Although journalistic efforts were made to identify the so-called 'New Left' with Marxism, traditional Marxism found few adherents in its ranks and it generated no support from the Soviet Union or China.

In the United States the counter-culture was directed most strongly against racial discrimination and the Vietnam War, and in these areas it found its widest allegiance. The anti-war activists outnumbered all others, with the result that the end of active United

Environmental Conservation, Vol. 1, No. 2, Summer 1974-(C) 1974 All Rights Reserved-Printed in Switzerland. 
States involvement in this war brought a cessation, for the time being, of most street marches and campus revolts. However, in other countries a more pervasive opposition to other social inequities was apparent, leading for example to the Paris rebellion of May 1968 (Priaulx \& Ungar, 1969), and perhaps as one of its lineal descendants the successful student overthrow of the military regime in Thailand in 1973.

From at least as early as 1966 , the counter-culture became in part an environmental movement, and the green 'ecology' flag was to be seen almost as often as the now-familiar peace symbol. The impetus of this mass-support for conservation in its broadest sense was of political significance particularly in the United States but also in the United Kingdom and Sweden. During the 1970 and 1972 elections in the United States, any congressman who was noted for his opposition to environmental legislation ran a strong chance of defeat, whereas many new faces were carried into Congress on environmental votes. The greatest visible and vociferous environmental support in the United States came during Earth Day, 1970, when any ecologist or would-be ecologist could find a large and enthusiastic audience. Internationally, youthful support for environmental causes appeared to build up to a peak for the United Nations Conference on the Human Environment, held in Stockholm in June 1972. The results of that Conference, and the general inaccessibility of its delegates during the meetings, proved a major disappointment for those who had expected more than 'business as usual.' For the more sophisticated, or world-weary, the creation of the United Nations Environment Programme was victory enough to move forward with.

\section{THE ENVIRONMENTAL MOVEMENT, DRUGS, AND RELIGIONS}

Although, along with the counter-culture, the environment movement is being written off by some media-men who are now obsessed with the "energy crisis' (as though this were a separate issue), I can only protest from my personal experience that it is still 'alive and well.' Indeed it seems likely to continue and grow further, as such problems will always be with us.

Of all the disturbing features of the counter-culture to the adherents of more traditional cultures (and there were few features that were not disturbing), one of the most extreme was its widespread adoption of psychedelic drugs. These caused no public outcry so long as their use was confined to ethnic minority groups or to a few explorers around the border areas of human consciousness such as Aldous Huxley and Humphrey Osmond, or even Timothy Leary. There was little in the way of legal sanction against marijuana or hashish, whereas LSD, mescalin, psylocibin, and the like, were virtually unheard of. However, when the children of the rich and of the middle classes began to experiment with these exotic substances, panic set in among parents and other guardians of public morality.

Perhaps the most positive feature of the new venture into psychedelic realms-and there were many negative features-was the opening of the mind to different views of reality. In opposition to those views of the world described by science and manipulated by technology, new visions were opened up. The world seemed no longer to remain in its staid and predictable format, but could be a place of magic-sometimes unbelievably beautiful and spiritually enlightening, sometimes unbearably frightening, but never dull. Such states of consciousness were scarcely describable or understandable to the followers of traditional JudaeoChristian religions, or to most believers in Islam, but had long been familiar to those who had ventured into realms of spiritual exploration following pathways laid down by the mystical western faiths, being more clearly marked by variants of Hinduism, Buddhism, Taoism, and other eastern beliefs. Thus Zen and Yoga became adopted-often in place of psychedelic drugsby counter-cultural adherents, and a great interest developed in so-called 'primitive' religions, particularly those of the American Indians.

Impetus towards following AmerIndian pathways to new states of conciousness gained with the publication of the Carlos Castaneda trilogy of books: The Teachings of Don Juan: a Yaqui Way of Knowledge (1968 [1969]); A Separate Reality: Further Conversations with Don Juan (1970 [1972]); and Journey to Ixtlan: The Lessons of Don Juan (1972). Castaneda, a student of anthropology at the University of California at Los Angeles, had taken up apprenticeship with a Yaqui Indian sorcerer in Sonora, Mexico, to explore the separate realities revealed by experience with peyote, datura, and sacred mushrooms. This led in time to realization of even more 'mind-blowing' experiences, following disciplines that involved no hallucinogenic substances at all.

Exploration of Zen and other eastern pathways to different forms of consciousness were particularly spurred by the influence of Alan Watts, himself a counter-cultural hero, and long-time student of eastern religious psychologies. In such books as The Meaning of Happiness (1940 [1968]) and The Book on the Taboo Against Knowing Who You are (1969 [1973]), Watts provided a western-oriented guide through the maze of eastern avenues to self-realization.

This entire movement was further spurred by the addition of fuel provided by the 'anti-psychiatry psychiatrists' such as R. D. Laing (The Divided Self, 1960 [1965]) and David Cooper (The Death of the Family, 1970 [1971]), as well as by the rediscovery of the works of the Swiss psychiatrist, Carl Jung. 
This interest in what had been considered, by most people in Europe and North America, to be exotic varieties of philosophy or psychology, led to a convergence with and reinforcement of concern with Nature and the environment. Carlos Castaneda, in his apprenticeship with Don Juan, entered realms of perception in which crows were messengers and what appeared to be coyotes or deer could prove to be spokesmen from other dimensions of reality. A 'reverence for life' that is reminiscent of Albert Schweitzer in the Christian tradition, colours every action of the Yaqui sorcerer. All things in Nature may have spiritual significance. One speaks to plants and apologizes for injuring them, and begs forgiveness from the rabbit one must kill for dinner. To seek to become 'a man of knowledge' in this Indian tradition, one must learn to 'see' and not just to 'look.' A heightening of awareness at the level of all five senses is a necessary condition for the development of spiritual awareness.

The pursuit of Zen leads to a convergence with ideas that emerge from ecology. This has caused David P. Barash to write of 'The ecologist as Zen master' in an article published in The American Midland Naturalist (1973). In any serious reflection on the functioning of ecosystems, the boundary of the 'individual' as defined by the western tradition of 'objective' thinking is found to get fuzzy and to disappear. One learns, early on, in ecology that the individual is coexistent with his environment, cannot be separated from it, and is continually changing and being changed by it. In psychology one learns how the individual is continually shaped and changed by interactions with other humans, and even when apart carries 'the others' within him. So too in Zen, as in other Oriental disciplines, the individual merges with all of the universe while still retaining his reality as an individual focus for universal forces. 'For God is not the One as distinct from the Many, nor unity as distinct from diversity. We cannot begin to understand the Oriental view of God until we can conceive of a "one" that can include both unity and diversity, which can at the same time be God and a speck of dust or a human being with equal reality' (Watts, 1940 [1968]).

It follows then that pursuit of the Tao, the way to realization, by Zen or other pathways leads to a conservationist viewpoint. 'The hostile attitude of conquering Nature ignores the basic interdependence of all things and events - that the world beyond the skin is actually an extension of our own bodies - and will end in destroying the very environment from which we emerge and upon which our whole life depends' (Watts, 1969 [1973]).

Popular interest in Oriental religions or the older creeds that Man held before the Judaeo-Christian civilization swept them away is not now confined to the counter-culture. Recent books on these subjects, if well-written, spring quickly into the ranks of bestsellers. Admittedly much of the interest is superficial or trivial, but a climate of public opinion is created in which those with more serious interest may find it easy to thrive.

\section{WITHDRAWAL FROM TECHNOLOGY}

An aspect of the counter-cultural revolt with particular relevance to the future of environmental conservation has been the withdrawal of great numbers of people from the ranks of the prevailing technological society in a search for alternative ways of life. The growth of the commune movement was phenomenal during the $1960 \mathrm{~s}$, and in these experimental communities new ways of living in urban or rural environments have been sought. It is easy to catalogue the failures of communes, since often the young and inexperienced people involved made every mistake known to students of human relationships and blundered badly in their attempts at agriculture. But many who failed learned from their failure, and still others succeeded. The land-based community, whether organized as group-living extended 'families' or as interacting and mutually supporting independent households, has been a means for exploring ways of crop production that are independent of the chemical industry or of fossil fuel energy. Some have been highly successful. Furthermore, the search for renewable sources of energy and successful development of small-scale technology using solar, wind, or water, power, may point to ways out of our energy dilemma. A society faced with dwindling supplies of fossil fuel and the high risk involved in nuclear-energy expansion may yet acknowledge a debt of gratitude to its countercultural pioneers. For an account of the development of the commune movement in the United States, Houriet (1973) is a useful reference. Further developments in alternative agriculture and technology are described regularly in The Ecologist, now published from Wadebridge, Cornwall, England.

Although journalists have buried the commune movement along with the counter-culture, it continues to thrive. Such experiments in living thrive best without publicity, and many have been killed in the past by the sheer weight of news-media attention.

Where the Wasteland Ends (Roszak, 1972) is primarily a devastating attack upon the 'single vision' of modern science, which, acting together with the dualistic thinking of Judaeo-Christian religion, has banished God from the visible universe and has left the Earth bare to attack from even the most misguided and illconceived advances of modern technology. Roszak finds that ' $O f$ course there is much science which is free of any reductionist intent. I do not dispute that for a moment. But reductionism-the turning of people 
and nature into mere, worthless things--is also part of science. It is part of the mainstream of science. It has been there from the outset. It continues in force today and has even increased its scope through the biological and behavioral sciences... Reductionism is quite simply inseparable from single vision.' After examining ways in which science and technology combine to turn mankind off from its own deepest feelings, to alienate people from themselves and the natural world, Roszak (ibid.) finds some hope in ecology and holds out a challenge to those who pursue its integrating inquiries: 'Ecology already hovers on the threshold of heresy. Will it be brave enough to step across and, in so doing, revolutionize the sciences as a whole? If that step is to be taken, it will not be a matter of further research, but of transformed consciousness. Kathleen Raine, in a single line of poetry, gives us the razor's edge of the issue neatly honed: "It is not birds that speak, but men learn silence." ,

'For many of our cultural drop-outs who have already that silence..., ecology represents a last tenuous connection with the scientific mainstream. It is the one science that seems capable of assimilating moral principle and visionary experience, and so of becoming a science of the whole person. But there is no guarantee [that] ecology will reach out to embrace these other dimensions of the mind. It could finish-at least in its professionally respectable version - as no more than a sophisticated systems approach to the conservation of natural resources. The question remains open: which will ecology be, the last of the old sciences or the first of the new?'

George B. Leonard's The Transformation (1972) does not feature attacks on science or technology as such but on their use for the purpose of Civilization, defined as 'that mode of social organization marked in general by political states, markets, legal sanctions, and social hierarchies, wherever in the world it occurs.' This Civilization, in return for material gain, systematically cuts its members off from their natural heritage, from the joy of being a member of the organic world, and from understanding of their own physical/mental realities. Its 'most indispensable nonmaterial endowment to its children is some type of neurosis/disease/discontent.' 'The Transformation' is the way out, not back towards primitive ways of life but through a new awakening on the part of people who realize, among other things, that Homo sapiens is not a species apart, but that 'there is only one species on this planet and its name is Life on Earth.' How we reach this point is not described precisely as it cannot be described, but 'after all the journeying, all the pain and joy, we may discover that the Transformation was difficult to grasp, not because it was so far away but because it was so very near. To find the immense world of delight is, in the end, to come home again, where it always was.'
It is not the purpose of this article to convert the unbeliever, but rather to call the attention of those whose eyes are glued to the technical journals of their disciplines that other game are also afoot. Such possibilities as yet may seem mere rustlings in the underbrush, but they appear to be converging on the ground that conservation occupies. Tomorrow's breakthrough may come, not from the field laboratory of ecology or ethology, but perhaps from an R. D. Laing (1967) who can say:

'I have seen the Bird of Paradise, she has spread herself before me, and I shall never be the same again.

'There is nothing to be afraid of. Nothing.

\section{'Exactly.}

'The Life I am trying to grasp is the me that is trying to grasp it.... 'If I could turn you on, if I could drive you out of your wretched mind, if I could tell you I would let you know.'

\section{SUMMARY}

Various social trends, not usually thought to be related to environmental conservation, are examined in relation to their impact on the conservation movement. The student rebellion of the 1960 s is seen as an important force backing environmental causes. Leading as it did to a 'return to the land' and the development of alternative life-styles, it may become a significant pioneering effort towards finding a more viable relationship between Man and his environment. As a further outgrowth of the development of a 'counterculture,' there is a renewed interest in those religious and psychological movements that seek to eliminate the dualities between body/mind, Man/Nature, matter/ spirit, long imposed by traditional western philosophy. This is seen as having a potential for major changes in human attitudes towards nature conservation.

\section{References}

Barash, David P. (1973). The ecologist as Zen master. American Midland Naturalist, 89(1), pp. 214-7.

Castaneda, Carlos (1968 [1969]). The Teachings of Don Juan: a Yaqui Way of Knowledge. University of California Press, Berkeley; Ballantine edn, 1969, New York: $276 \mathrm{pp}$.

CASTANEDA, Carlos (1970 [1972]). A Separate Reality: Further Conversations with Don Juan. Simon \& Schuster, New York; Pocket Books edn, 1972, New York: $263 \mathrm{pp}$.

CASTANEDA, Carlos (1972). Journey to Ixtlan: The Lessons of Don Juan. Simon \& Schuster, New York: 315 pp.

CoOper, David (1970 [1971]). The Death of the Family. Random House, New York; Vintage Books edn, 1971, New York: 145 pp.

Houriet, Robert (1973). Getting Back Together. Abacus, Sphere Books, London: 379 pp. 
LAING, R. D. (1960 [1965]). The Divided Self. Tavistock Publications, London; Pelican edn, 1965, Penguin Books, Harmondsworth: $218 \mathrm{pp}$.

LAING, R. D. (1967). The Politics of Experience. Ballantine Books, New York: $190 \mathrm{pp}$.

LeonarD, George B. (1972). The Transformation. Delacorte Press, New York: $258 \mathrm{pp}$

Priaulx, Allan \& Ungar, S. J. (1969). The Almost Revolution-France-1968. Dell, New York: $177 \mathrm{pp}$.

REICH, Charles A. (1970 [1971]). The Greening of America. Random House, New York; Bantam Books edn, 1971, New York: 433 pp.

ReVEL, Jean-François (1971 [1972]). Without Marx or Jesus. The New American Revolution Has Begun. Doubleday, New York; Paladin edn, 1972, London: $222 \mathrm{pp}$.
Roszak, Theodore (1968 [1971]). The Making of a Counterculture: Reflections on the Technocratic Society and its Youthful Opposition. Faber \& Faber edn, 1971, London: $303 \mathrm{pp}$.

Roszak, Theodore (1972). Where the Wasteland Ends. Doubleday, New York: $492 \mathrm{pp}$.

WATTS, Alan (1940 [1968]). The Meaning of Happiness. Harper \& Row, New York; Perennial Library edn, 1968, New York: 219 pp.

WATTs, Alan (1969 [1973]). The Book on the Taboo Against Knowing Who You Are. Sphere Books, London; Abacus edn, 1973, London: 142 pp.

Wolfe, Tom (1968 [1969]). The Electric Kool-aid Acid Test. Farrar, Straus \& Giroux, New York; Bantam Books edn, 1969, New York: 372 pp.

\section{Changing Perspectives of the Sierra Club}

Founded in 1892 by John Muir, the Sierra Club was first organized as an association of 182 mountaineers and naturalists dedicated to the preservation of wilderness. From the outset the Club's actions showed it to be an effective spokesman for wilderness and a formidable opponent of all special interests threatening the natural environment.

During its first year of existence, the Club was a major force in the defeat of a proposal to reduce the boundaries of Yosemite Park. The following year, forest reserves were established through the Club's urgings, and in 1895 it was active in seeking protection of the Grand Canyon, Mount Rainier, and the Coast Redwoods (Sequoia sempervirens, the world's tallest living tree). These early efforts set the pattern for the continuing activities of the Sierra Club over the years.

Today, the Club has grown to over 140,000 members, with 44 chapters in the United States and Canada. Furthermore, the chapters contain almost 200 local 'groups' and an elaborate structure of national and regional committees focusing their attention on particular areas of conservation concern.

In addition to its North American headquarters in San Francisco, California, and an office for representation in Washington, D.C., the Club has regional offices throughout the United States and at the United Nations in New York City. It also has volunteer representatives in Rome, Geneva, Paris, London, and Nairobi.

The Sierra Club Foundation was incorporated in 1960 as a means of guaranteeing tax-deductibility of gifts to the Club. In 1968 the U.S. Internal Revenue Service ruled that the Sierra Club itself could no longer receive tax-deductible contributions because of its degree of involvement in legislative affairs. The Foundation assumed responsibility for the receipt of deductible contributions for the nonlegislative programme of the Club: educational, legal, scientific, international, and publications.

The Foundation now administers its own related programmes and contributes to those of other conservation organizations. It also receives and disburses funds raised by certain other environmental organizations as an additional service, providing the assistance of its staff as well as the benefits of tax-deductibility to donors.

In the last few years, the Club has found it increasingly necessary to turn to the courts to obtain compliance with the letter and spirit of environmental laws passed by Congress and the state legislatures. The legal work is handled or overseen by the Sierra Club Legal Defense Fund, which employs several attorneys. This staff is aided by publicspirited attorneys who receive only a modest fee or merely expenses for their valuable services. The Legal Defense Fund now has to its credit over 80 cases nationwide and has been especially instrumental in securing decisions preserving air quality and protecting wilderness.

In the knowledge that wilderness will be preserved only in proportion to the numbers of people who know its values first-hand, Sierra Club outings strive to be not only enjoyable vacations, but also vital lessons in the need to preserve wilderness and use it properly. Each year there are over 150 wilderness outings sponsored by the North American headquarters. They range from a week of family camping close to home to a six-weeks trek in the Himalayas. Local chapters and groups sponsor thousands of local outings.

The Sierra Club Office of International Environmental Affairs was opened in April 1972. At that time the Sierra Club played an active role in preparations for the United Nations Conference on the Human Environment, Stockholm. It is now focusing on specific areas that were identified as major global problems at that Conference, such as tropical forestry and marine pollution. This programme includes cooperation with non-governmental organizations throughout the world, and the Club has prepared the first World Directory of Environmental Organizations.*

While initially the Club was concerned chiefly with the preservation of the Sierra Nevada in California, its interests have thus broadened extensively, particularly in the last few. years, to include a wide range of global environmental issues.

In the recent past, the Sierra Club has sought expansion of the National Wilderness Preservation System in the U.S. by pushing for a full review of all roadless areas in the national forests. The Club also led the way in protecting the forests from excessive cutting by the timber industry, expanding the National Park System, revising outdated American public land legislation, and preserving public lands in Alaska; it also helped significantly in bringing about the defeat of the proposed supersonic transport, protecting coastal land, and urging establishment of 'Urban Recreation Areas' along the headlands of San Francisco Bay and New York Harbor.

Today the top priorities of the Club are our continuing efforts to ensure preservation of public lands, responsible use of private land, and the conversion to a more rational, steady-state energy system.

Michael McCloskey, Executive Director Sierra Club

Mills Tower, San Francisco

California 94104, U.S.A.

* See the review on page 160 of this issue. - Ed. 